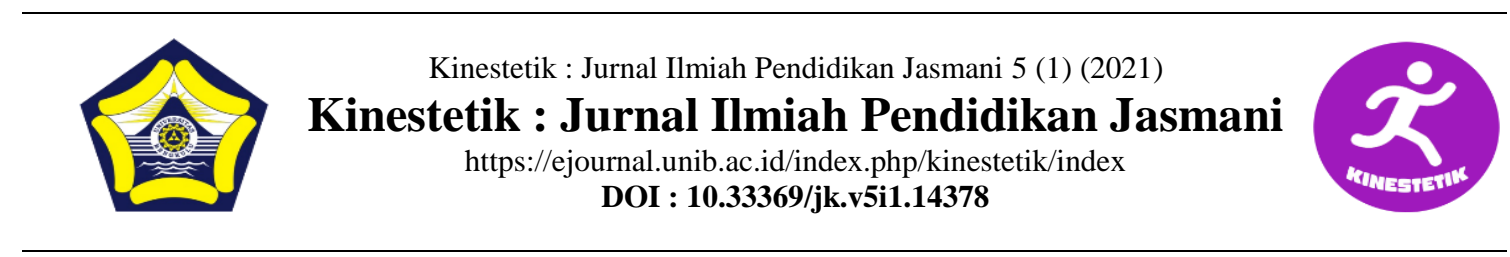

\title{
DISABILITY SPORTS ACHIEVEMENTS OF INDONESIAN SPECIAL SCHOOLS OF DISABILITY STUDENTS
}

\author{
Tesalonika Kurnianugraha ${ }^{1 *}$, Erma Kumala Sari $^{2}$, Mohammad Anwar ${ }^{3}$, Djoko \\ Nugroho $^{4}$ \\ ${ }^{1234}$ Sebelas Maret University : Spesial Education, Teacher Training and Education Faculty, \\ Universitas Sebelas Maret, Surakarta, Indonesia
}

\section{Article Info \\ Article History : \\ Received : February 2021 \\ Revised : February 2021 \\ Accepted : March 2021 \\ Available online : March 2021}

\section{Keywords:}

disability, physical, psychological, social, supporting, Sports achievement

\begin{abstract}
This study aims to describe the achievements of disability sports students of Indonesian disability sports special schools and students with achievements in sports with disabilities in outstanding schools in peparpenas 2019. This study uses the qualitative research method. The subjects in this study were coaches and teachers of the Indonesian Special School for Disability Sports and Students with Achievements in Disability Sports in Outstanding Schools. Sampling techniques in this study used purposive sampling techniques. Data analysis techniques used are data reduction, data exposure, conclusion and verification. The results showed that (i) Physical as a form and can be seen by the naked eye, which is also a supporting element in improving the achievements of children with special needs in the sport of athletics consists of providing nutritional intake, and organ function; (ii) Psychological motivation, understanding the intellectuals of children with special needs, personality, and personality as one of the supporting achievements in the sport of athletics; (iii) Social support from friends, parents, family, teachers/trainers, and schools; and (iv) Supporting facilities and infrastructure, training, trainers, teachers, other skills, and organizational structure. The results of this study can be concluded that the achievements of sports students with disabilities in sports special schools with disabilities in Indonesia and students with sports disabilities in schools with achievement are physical, psychological, social, and support.
\end{abstract}

\footnotetext{
Corresponding address $\quad$ : Jl. Menteri Supeno, Manahan, Kecamatan Banjarsari, Kota Surakarta

*Corresponding email : tesalonikak13@gmail.com

ISSN 2685-6514 (Online) ISSN 2477-331X (Print)
} 


\section{INTRODUCTION}

Children with special needs are then abbreviated as CSN children who have limitations, both physical, mentalintellectual, social, and emotionally influential in the process of growth and development compared to other children his age (Khairun Nisa et al., 2018; Khairunisa Rani et al., 2018). Therefore, the need for teaching social skills models to children with autism spectrum disorders (Pickle et al., 2017).

Early Child Development and Developmental Delay in Indigenous Communities (Cappiello \& Gahagan, 2009). (Fegert et al., 2020) suggests the need for clinical needs to treat children with special needs. (Gillberg, 2010) Early Symptomatic Syndromes Eliciting Neurodevelopmental Clinical Examinations. (Ringeisen et al., 2008) Special health care needs among children in the child welfare system. (Fletcher \& Vaughn, 2009) it takes a positive response to prevent children's learning difficulties. But children with special needs also get the same rights as children in general, including in terms of education, and accessibility. Stipulated in The Indonesian Replubik Law number 23 of 2002 in article 51 (Indonesia, 2014; Pemerintah Republik Indonesia, 2002, 2014) "children with physical and/or mental disabilities are given equal opportunities and accessibility to obtain an outstanding education.". Therefore, children with special needs have the same opportunity in achieving achievements in both academic and non-academic fields.

CSN's achievements are not much different from children in general. They get the same right to develop the achievements they will achieve. One of them is achievement sports children with special needs equivalent to normal children in general. The government's efforts to grant rights to children with special needs start with normal children
Law of the Republic of Indonesia Number 3 the Year 2005 on the National Sports System (UU RI Nomor 3, 2005), Part Seven " Coaching and Development of Sports With Disabilities Article 30 paragraph 1 says that "Coaching and development of sports with disabilities is carried out and directed to improve health",

Fostering and developing sports with disabilities is not easy or easy, the need for systematic and structured coaching. (Jariono \& Subekti, 2020) To improve achievement, the need for motivation to exercise. (Ansori, 2020) suggests that a circuit game approach is needed to generate motivation for children. This is in line with the stated (Fadlih, 2019) one of the subjects to enhance the motivation and learning interest of children's disability through physical education learning. (Hidayatullah \& Pranowo, 2018) suggests that there is a need for socialization for people with disabilities. (Kliwon \& Sarwanto, 2019) to improve performance for people with disabilities the need for regulation. (Pratama \& Hudah, 2020) the existence of regulations so that the achievements of athletes with disabilities have room to develop their talents and interests. (Pujarina \& Kumala, 2019) suggests the psychology of children with disabilities is the determining factor of performance. (Penggalih et al., 2018) to improve the achievement of athletes with disabilities the need for nutritional equality. It means that in fostering and training CSN needs synergy between sports players, parents, environment, and stakeholders into an inseparable unity to increase the degree of confidence in CSN to achieve a qualified achievement and foster confidence, and sports achievement.

One of the containers to foster and train CSN is in a special school of Indonesian sports then abbreviated as 
SKODI. SKODI is a special school designed to accommodate athletes with student-level disabilities who are gathered from several regions in Indonesia to be nurtured and guided by the potential of disability sports in achieving achievements from the regional level to the national level, even to the international level. (Firdaus \& Hartono, 2020) for people with disabilities is centered on special sports training to improve achievements. (Hakim, 2017) children with special needs need a special approach through adaptive education learning. (Pertiwi et al., 2018) improve systematic movement in children with special needs the need for one of the strategies through circuit learning. (Wardah, 2019) suggested that the role of teachers to improve the learning of students with special needs. (Widodo et al., 2020) presented the identification of talents of children with special needs as one of the supporting achievement improvement. (Yuliawan, 2017) policy of managing the assessment of children with special needs to improve children's performance. The existence of a forum to build abk is a fresh wind for the people of Indonesia and even the world to foster and train children with special needs in contributing to lift the dignity and dignity of the country, one of which is through achievements in the field of sports.

SKODI limitations make all children with special needs who excel in sports unable to enter and process together. This is because the limited capacity of the student admissions system, facilities, and infrastructure that can only accommodate a few athletes selected in the selection is the main reason for the limited power accommodated. One of the requirements to enter the SKODI is a child with special needs who excels in the event and the first winner or gold medal in the implementation of multi-event sports with disabilities. Children with special needs who excel in disability sports in The Extraordinary School are fostered to follow an adaptive educational curriculum in the development of their sports achievements. (Kiuppis, 2018) is an insurrection in sports as a means for sports with disabilities. (Penney, 2003) sports learning as an alternative to improving children's learning motivation. (Penney \& McMahon, 2016) sports learning is one of the horizons of sports pedagogy. (Pitts \& Shapiro, 2017) for people with disabilities the need for sports management to achieve achievements. (Sit et al., 2002) stated the need for the participation of children with special needs to socialize the wider community to improve sports performance. Therefore, specializes in following the sport owned by the child. The facilities and infrastructure in the Extraordinary School are used for the development of the achievements of children with special needs. Based on the phenomenon in the form of fact, researchers only limit to children with special needs who participate in the National Student Paralympic Week (PEPARPENAS) especially the sports of athletics (S. Mudjianto et al., 2017; Sufyar Mudjianto et al., 2018). One of the considerations of limiting this problem in the sport of athletics, especially in central Java because of the limited time, cost, energy, and reach of the subject and the outbreak of Covid_19 disease that panicked people around the world. However, it does not limit researchers to research how to solve the problem so that researchers remain productive in the field of research.

This is supported by the observations of researchers on January 20, 2020, namely achievement data obtained from National Paralympic Indonesia (NPC) Central Java said, Outstanding School students won several 
sports with disabilities at several disability sports events. One example in Sragen Extraordinary School is that there are 3 children with special needs who won the National Student Paralympic Week (PEPARPENAS) event. Therefore, the achievements of children with special needs can now be seen as a real equivalent to the achievements of general sports.

Based on the background of the above problems, the achievements of athletics athletes achieved by students with special needs who participated in the PEPARPENAS 2019 sports championships for students of the Indonesian Special School of Disability Sports and Extraordinary Schools can be observed further to get more information. Thus, this researcher was titled "Disability Sports Achievements of Indonesian Special School Students with Disabilities and Outstanding Students in Outstanding Schools in PEPARPENAS 2019"

\section{METHODS}

The descriptive research method using the qualitative research approach used by this study consists of observation, interview, and documentation, and dissemination of questionnaires to strengthen the results of this research.

\section{Participants}

This research was conducted at the Indonesian Disability Sports Special School (SKODI), and 3 (three) Extraordinary Schools (SLB) of Jawa Tengah Province, namely Sragen State SLB, Surakarta State SLBS, SLBS Surya Gemilang Kendal overall the subject of this study 16 subjects of each school consisted of 4 (four) athletic trainers, 4 (four) class teachers, 4 (four) viceprincipals in the field of student affairs and 4 (four) principals. Researchers chose the Indonesian Disability Sports Special School and The Extraordinary School in Jawa Tengah because of the following considerations.

1) The Indonesian Special Disability Sports School is the first disability sports achievement center school in Indonesia so that the public knows a lot of information about SKODI.

2) The location of The Extraordinary School in Jawa Tengah is an area that achieves outstanding disability sports achievement through the results of the first rank in the national event.

\section{Sampling Procedures}

This sampling procedure by purposive sampling, because this study considers the characteristics of the student's gender, research area, and a special school for children with disabilities.

\section{Materials and Apparatus}

Data collection techniques are carried out in four techniques, namely observation, interviews, questionnaires, and documentation. The description is as follows.

1) Observations were made to check directly the condition of the subject in the exact research. observations were made adjusting the conditions in SKODI and SLB. In this study, researchers used frank or disguised observations. To avoid a data searched is a confidential data As for the observation grid can be seen in the following table:

Table 1 Observation Grid for achievements of sports with disabilities in athletics

\begin{tabular}{|c|c|}
\hline $\begin{array}{l}\text { General } \\
\text { Aspects } \\
\end{array}$ & Special Aspects \\
\hline $\begin{array}{l}\text { Para Athletics } \\
\text { Achievements }\end{array}$ & $\begin{array}{l}\text { a. The results of the } \\
\text { acquisition of the medal }\end{array}$ \\
\hline
\end{tabular}




\begin{tabular}{lll}
\hline \multicolumn{1}{c}{$\begin{array}{c}\text { General } \\
\text { Aspects }\end{array}$} & \multicolumn{1}{c}{ Special Aspects } \\
\hline Human & b. & Training program \\
Resources & a. & Trainer skills \\
& b. & $\begin{array}{l}\text { Number of students } \\
\text { who excel in sports with } \\
\text { disabilities in para- } \\
\text { athletics }\end{array}$ \\
& a. Facilities and \\
Supporting & Infrastructure \\
Achievements & b. Nutritional Intake \\
& c. Pocket money/intensive \\
\hline $\begin{array}{l}\text { The subject's } \\
\text { attitude during } \\
\text { the interview } \\
\text { is on the line }\end{array}$ & a. $\begin{array}{l}\text { bisible facial } \\
\text { expressions/movements }\end{array}$ \\
\hline
\end{tabular}

2) Interviews are conducted to obtain information related to the achievements of children with special needs in the sport of athletics. The interview guidelines grid can be seen in the following table:

Table 2. Research interview grid

\begin{tabular}{ll}
\hline \multicolumn{1}{c}{ Aspects } & \multicolumn{1}{c}{ Indicators } \\
\hline Physical & a. Nutritional Intake \\
& b. Organ Function \\
& c. Exercise \\
\hline Psychological & d. Motivation \\
& e. Intellectual property \\
& f. Personality \\
\hline Social & a.Friend support \\
& b. Family support \\
& c.Coach support \\
\hline Support & a. Facilities and \\
& b. Infrastructure \\
& c. Other skills \\
&
\end{tabular}

3) Documentation related to photos or achievement records of Students of the Indonesian Special School for Disability Sports and students with achievements in disability sports in the Extraordinary School of athletics. In this study, researchers used documents related to the problems and objectives of this research, as well as a tool to collect document data in this study. The documentation in the research can be described as follows: a) Achievements of athletes with disabilities at PEPARPENAS 2019

b) Program exercise students with achievements in disability sports at the Special School of Sports Disability Indonesia and students with achievements in disability sports in the Extraordinary School, which includes SLB Negeri Sragen, SLB Negeri Surakarta, SLBS Surya Gemilang Kendal athletics

c) PEPARPENAS 2019 handbook

d) The organizational structure of The Special School of Disability Sports Indonesia and the development of disability sports achievement in The Extraordinary School, which includes Sragen State SLB, Surakarta State SLBS, Surya Gemilang Kendal SLBS

e) Decree to become a coach of para athletics

f) Charter awards outstanding students sports disability branch of the athletics

g) Certificate of coach coaching athletes with disabilities

\section{Procedures}

This research consists of several research steps, namely:

1) Researchers conducted observations in SKODI and SLB Jawa Tengah to obtain a direct picture of the condition of the subject used as research material;

2) Develop interview instruments that have been validated by experts consisting of children with special needs, experts of the National Paralympic Committee Indonesia (NPC), and coaches of the National Paralympic Athletics Committee Indonesia (NPC). The validators are: (1) DSR is a Special Needs Child Expert Lecturer of Extraordinary 
Education UNS; (2) W is the Chairman of the National Paralympic Achievement Development Committee Indonesia (NPC) Lecturer of the Faculty of Sports UNS, and (3) SW is the National Athletics Coach of the Paralympic Committee Indonesia (NPC) Lecturer of the Faculty of Sports UNS (primary data source in 2020).

3) Next do triangulate data done to legality check to strengthen from the interview result data

\section{Design or Data Analysis}

Data analysis in this study consists of data reduction, data display, and verification. Data reduction is an activity to collect data related to the achievements of para athletic athletes, display data is used to briefly describe obtaining data from the results of interviews, while verification of data is used to conclude the findings of research on the achievements of children with special needs athletes in the sport of para-athletics.

\section{RESULT}

Based on the results of research on the achievements of students of special sports schools with disabilities and outside schools can be the results of observations images of research, interviews, and research documentation. these results are described as follows:

\section{1) Observation results}

This observation described describing the research location. The study was conducted in four places. The first location is in the Indonesian Disability Processing Special School located at street Doktor Moewardi No.44, Mangkubumen, Banjarsari District, Surakarta City, Jawa Tengah is a four-star hotel located in Surakarta City, the next location is the
Extraordinary School (SLB) located in Jawa Tengah. These three SLB are SLB who have outstanding students with disabilities in perpends 2019, including SLB Country Surakarta which has mangkubumen address, Banjarsari District, Surakarta City, Jawa Tengah, then Sragen State SLB located on Kalibening Street, Kroyo, Karangmalang, Sukorejo, Kroyo, Karangmalang District, Sragen Regency, Jawa Tengah, and the last location is in SLBS Surya Gemilang Kendal City with a location on Jalan Raya Utara Margosari No.5a, Krajan, Margosari, Limbangan, Kendal Regency, Jawa Tengah.

The four research locations of researchers conducted the study alternately in a period of 31 days starting from October 21, 2020, to November 21, 2020 , with details of the research data as follows; research at the Indonesian Special School for Disability Sports was conducted on Thursday 29 October 2020 and Saturday 14 November 2020, SLB Negeri Surakarta was held on Thursday, October 22, 2020, and Friday, October 23, 2020, Sragen State SLB was held on Tuesday, October 27, 2020, and SLBS Surya Gemilang Kendal was held on Wednesday, November 18, 2020, and Saturday, November 21, 2020.

2) Interview result

The results of this interview concluded from the findings of data from interviews with subjects about (1) physical intake consisting of nutrition, organ function, and exercise; (2) Psychological consists of motivation, intelligence, and personality; (3) social consists of friend support, family support, and coach support; and (4) supporting facilities consisting of infrastructure, other expertise, and organizational structure. The results of 
the interview can be described as follows:

a) consisting of nutritional intake, organ function, and exercise

Importance of understanding of children with special needs bag community both within the family and outside the family environment. In the family, the environment means to support or support the next of kin while support outside the family environment is the surrounding community about children with special needs. The following description of interviews conducted with sports teachers, deputy heads of student affairs, principals, and parents, as for the results of the interview can be described as follows:

A person who has a physical disability to excel in one of the sports, especially athletics related to nutrition intake, organ function, and exercise, is not always retarded in various fields, surely a person who lives in this world has their advantages and weaknesses. Therefore, a person who has a disability does not need to be looked at eye to eye, and the best attitude and all we have to do is not discriminate between position, physical condition, or social status in getting along with "(interview with WI, Wednesday, October 21, 2020). In line with AN Wednesday, October 21, 2020, related to the sports achievements of children with special needs about nutrition intake, organ function, and exercise aspects is a unity that can not be separated from each other to achieve achievements. This means that when viewed and observed by children with special needs, it is necessary to pay attention both when following the teaching and learning process and in training. These results are confirmed by athletic trainers who know exactly about the characteristics of children with special needs both during training and resting. Therefore, the intake of nutrition, organ function, and exercise is one of the supports to improve the achievements of athletes.

b) Psychologically consists of motivation, intelligence, and personality

A child with special needs has a physical or mental disorder, which can be disruptive or is an obstacle and obstacle for him to do properly. Everyone is entitled to a job. The interview results are as follows; Psychological consists of motivation, intelligence, and personality is a psychic state of children with special needs to achieve achievements, especially in the sport of athletics one of special treatment with children with special needs is by communicating is one of the ways humans survive, whoever the human being is (the result of an interview with, Thursday, October 21, 2020). This is in line with what MS stated (Thursday 21 October 2020) As a form of meeting human needs, communicating will make it easier for others to understand what is intended. The statement was reinforced by one of the parents of the students ( the results of an interview with HR Wednesday, October 21, 2020) Various ways of communicating are many, some only use words and some are also in the form of body movement images, or even use both. The results were confirmed by athletic trainers that "communication with Disability is the same as communicating with NonDisability. The difference is, there are several word choices to choose from. Like the word 'Normal', the use of this 
word should be changed using the word 'Non-Disability'. The word normal can mean different, as if the disability is not a normal person" the result of an interview with HR Thursday, October 22, 2020).

c) Social consists of friend support, family support, and coach support The existence of children with special needs by asan oknum is still seen in the eyes. The community should treat children with special needs well because they also have the same rights that have been regulated by law. The results of the interview about the social response consisted of friend support, family support, and coach support as follows:

The preservice social basis for children and adolescents with special needs becomes one of the keys to their growth. And this is not only the duty of the government but also requires the participation of all components of society, especially in the aspects of education services, health services, the provision of public infrastructure that is friendly for the disabled, to the program of empowerment of people with disabilities ( the results of an interview with the Hospital Thursday, October 21, 2020. This is following the statement of SH (Thursday 21 October 2020) needs to be straightened out the paradigm of some parents and core families and communities who are often still mistaken for the existence of children and adolescents with special needs, it is necessary to build cohesiveness and togetherness between parents and the social environment to support the growth of children and adolescents with special needs.

The results of the interview were confirmed by MR Thursday, October 21, 2020, the existence of support specifically for the family to be and the key community to realize family resilience, which is the foundation of the formation of community resilience and because the family is the smallest unit in the community

d) Support consists of infrastructure, other expertise, and organizational structure

Efforts to fulfill and protect the rights of children with special needs related to infrastructure, other skills, and organizational structure have shown positive development in recent years. The interview results are as follows;

The rights of children with special needs are contained in law No. 8 of 2016 guaranteeing the protection and fulfillment of the rights of children with special needs in Indonesia starting a new era. In the act, it is clear that the rights of children with special needs are guaranteed by law (the results of an interview with $\mathrm{KR}$ on Thursday 21 October 2020). The results are similar to those presented by MR Thursday, October 21, 2020) the rights of persons with disabilities are contained not only guarantees in the Constitution of 1945 and Law No. 8 of 2016, Article 5 paragraph (3) of Law No. 39 of 1999 on Human Rights has mandated that everyone who belongs to the vulnerable community has the right to more treatment and protection concerning its specificity.

The results of some of these aspects can be concluded that (1) physical consisting of nutritional intake, organ function, and exercise; (2) Psychological consists of motivation, intelligence, and personality; (3) social consists of friend support, family support, and coach support; and (4) supporting 
facilities consisting of infrastructure, other skills, and organizational structure is an inseparable unity in fostering and training children with special needs in achieving achievements, especially in the sport of athletics.

\section{3) Research Documentation}

Documentation was collected to corroborate the results of interviews and questionnaires on Disability Sports Achievement of Students of the Indonesian Special School of Disability Sports. The research documentation can be seen in the following figure:

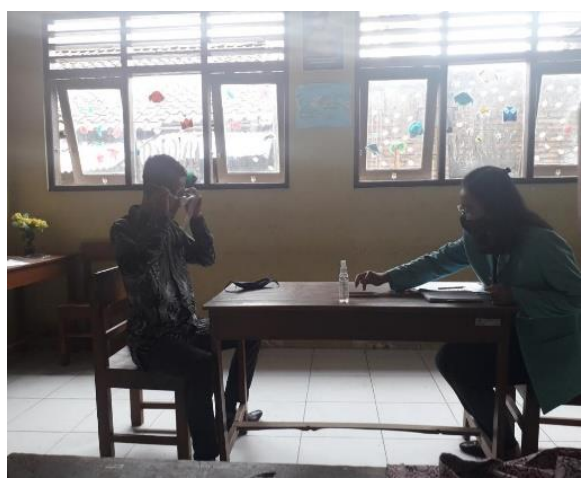

Figure. 1 researcher interviewed the subject of one of the SLB school principals

Disability Sports Achievement Students of The Indonesian Special School of Disability Sports need a long struggle to achieve achievements from the regional, national, and international levels. The result of the documentation is the interview process with the research subjects of administrators.

\section{4) Results of questionnaires}

distributing

The results of the dissemination of questionnaires to the study subjects consisted of (1) physical which consisted of nutritional intake, organ function, and exercise; (2) Psychological consists of motivation, intelligence, and personality; (3) social consists of friend support, family support, and coach support; and (4) supporting facilities consisting of infrastructure, other expertise, and organizational structure. Quantitative results can be seen the results of descriptive analysis of the following table:

Table 3. Recapitulation of descriptive analysis

\begin{tabular}{ccc}
\hline Statement & $\begin{array}{c}\text { Number of } \\
\text { respondents }\end{array}$ & $\begin{array}{c}\text { Average } \\
\text { percentage }\end{array}$ \\
\hline Strongly agree & 12 & $75.00 \%$ \\
\hline Agree & 3 & $18.75 \%$ \\
\hline Undecided & 1 & $6.25 \%$ \\
\hline Disagree & 0 & $0.00 \%$ \\
\hline $\begin{array}{c}\text { strongly } \\
\text { disagree }\end{array}$ & 0 & $0.00 \%$ \\
\hline Total & 16 & $100,00 \%$ \\
\hline
\end{tabular}

Based on the results of a descriptive analysis of data on Disability Sports Achievement Students of the Indonesian Special School of Sports Disabilities it can be concluded that the average coach, sports teacher, deputy principal of student affairs, principal, and parents of students strongly agree if in training and fostering children with special needs synergize with each other consisting of (1) physical which consists of nutritional intake, organ function, and exercise; (2) Psychological consists of motivation, intellectual, and personality; (3) social consists of friend support, family support, and coach support; and (4) supporting facilities consisting of infrastructure, other expertise, and organizational structure. . This is evidenced by the dissemination of a poll of 16 respondents there were 12 respondents agreed or $66.67 \%$ about The Achievement of Disability Sports Students of The Indonesian Special School of Disability Sports in the category of excellent can be seen in the following histogram; 


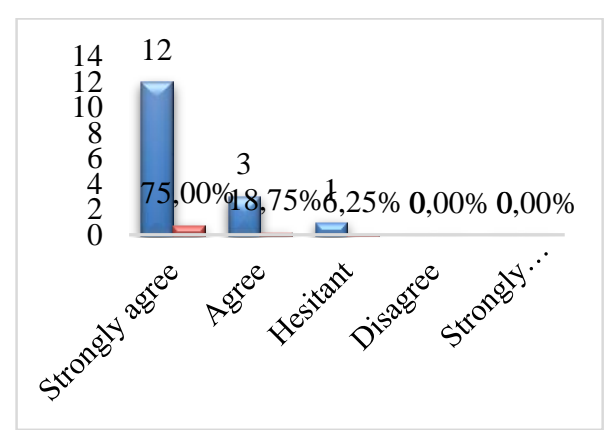

Figure 5. histogram sports achievement disability students special school sports disability Indonesia

\section{DISCUSSION}

The results of observations, interviews, questionnaires, and documentation in this study give the meaning that the achievements of children with special needs are equivalent to normal children in general. This means that children with special needs have the space to express themselves and show the world that they are capable of achievement following the characteristics of the child. In this study, there are four important points, namely physical aspects, psychological aspects, social aspects, and supporting aspects.

A physical spec on Indonesian disability sports special school athletes. physical aspects include nutritional intake, organ function, and exercise. every athlete from Indonesia's special school of disability sports and the outstanding school has classification differences. three elementary school athletes participated in the 2019 peparpenas competition in the paraathletics sport.

Aspec a psychologist, the subject acts as a motivator and inspiration. each subject has its way of dealing with athletes who are not highly motivated and motivated. several circumstances require coaches to give special treatment to athletes, among them the mood of the athletes is fickle, some athletes are lazing around, and some athletes feel saturated with the training process

A social spec subject performs the role of a coach by providing support predominantly. in his role as a coach, the subject provides support by educating, motivating, and providing vitamins as a guard of endurance.

A supporting spec relating to the facilities and infrastructure provided to athletes. athletes as persons with disabilities need to get complete facilities and infrastructure following standards

The results showed that (i) physical as a form and can be seen by the naked eye, which is also a supporting element in improving the achievements of children with special needs in the sport of athletics consists of providing nutritional intake, and organ function; (ii) psychological motivation, understanding the intellectuals of children with special needs, personality, and personality as one of the supporting achievements in the sport of athletics; (iii) social support from friends, parents, family, teachers/trainers, and schools; and (iv) supporting facilities and infrastructure, training, trainers, teachers, other skills, and organizational structure.

\section{CONCLUSION}

Based on the results of the study, it can be stated that the achievement of disability sports students special school sports disability indonesia (1) physical consisting of nutritional intake, organ function, and exercise; psychologically consists of motivation, intelligence, and personality; (3) social consists of friend support, family support, and coach support; and (4) supporting facilities consisting of infrastructure, other expertise, and organizational structure in a very good category. However this study only examined one of the sports of athletics, then researchers 
inning conducted a study on the improvement of athletes' achievements of athletics reviewed from the social environment, motivation to train, and related to the improvement of sports achievement disability students special school sports disability Indonesia.

\section{ACKNOWLEDGEMENT}

Thanks to the university eleven march Surakarta has allowed researchers to conduct research and School special sports disability Indonesia (SKODI)) extraordinary school (SLB) Jawa Tengah province has helped researchers in preparing the subject and took the time to help in data retrieval.

\section{REFERENCES}

Acar, C., Tekin-Iftar, E., \& Yikmis, A. (2017). Effects of Mother-Delivered Social Stories and Video Modeling in Teaching Social Skills to Children With Autism Spectrum Disorders. Journal of Special Education.

https://doi.org/10.1177/0022466916649 164

Ansori, S. (2020). Pengaruh Permainan Sirkuit Terhadap Motivasi Belajar Pendidikan Jasmani, Olahraga Dan Kesehatan Siswa Disabilitas Rungu. Jurnal Pendidikan Olahraga Dan Kesehatan.

Fadlih, A. M. (2019). Minat dan Motivasi Peserta Didik Penyandang Disabilitas Ketunarunguan terhadap Mata Pelajaran Pendidikan Jasmani Kesehatan dan Olahraga. Musamus Journal of Physical Education and Sport (MJPES). https://doi.org/10.35724/mjpes.v2i01.20 72

Fegert, J. M., Vitiello, B., Plener, P. L., \& Clemens, V. (2020). Challenges and burden of the Coronavirus 2019 (COVID-19) pandemic for child and adolescent mental health: A narrative review to highlight clinical and research needs in the acute phase and the long return to normality. In Child and
Adolescent Psychiatry and Mental Health. https://doi.org/10.1186/s13034020-00329-3

Firdaus, M., \& Hartono, R. (2020). Pusat Olahraga Untuk Difabel Banjarbaru. JTAM Lanting.

Gillberg, C. (2010). The ESSENCE in child psychiatry: Early Symptomatic Syndromes Eliciting Neurodevelopmental Clinical Examinations. Research in Developmental Disabilities. https://doi.org/10.1016/j.ridd.2010.06.0 02

Hakim, A. R. (2017). Memuliakan Anak Berkebutuhan Khusus Melalui Pendidikan Jasmani Adaptif. Jurnal Ilmiah Penjas.

Hidayatullah, A. N., \& Pranowo, P. (2018). Membuka Ruang Asa dan Kesejahteraan Bagi Penyandang Disabilitas. Jurnal Penelitian Kesejahteraan Sosial.

Indonesia, R. (2014). Undang-Undang Nomor 35 Tahun 2014 tentang Perubahan Atas Undang-Undang Nomor 23 Tahun 2002 Tentang Perlindungan Anak. Undang Undang.

Jariono, G., \& Subekti, N. (2020). Sports Motivation Survey And Physical Activity Students Of Sport Education Teacher Training And Education Faculty FKIP Muhammadiyah University Surakarta. Kinestetik : Jurnal Ilmiah Pendidikan Jasmani. https://doi.org/10.33369/jk.v4i2.12449

Khairun Nisa, Mambela, S., \& Badiah, L. I. (2018). Karakteristik Dan Kebutuhan Anak Berkebutuhan Khusus. Jurnal Abadimas Adi Buana. https://doi.org/10.36456/abadimas.v2.i1 .a1632

Khairunisa Rani, Rafikayati, A., \& Jauhari, M. N. (2018). Keterlibatan Orangtua Dalam Penanganan Anak Berkebutuhan Khusus. Jurnal Abadimas Adi Buana. https://doi.org/10.36456/abadimas.v2.i1 .a1636

Kiuppis, F. (2018). Inclusion in sport: disability and participation. In Sport in Society. https://doi.org/10.1080/17430437.2016. 1225882

Kliwon, K., \& Sarwanto, A. (2019). Pengaruh 
Aktivasi Regulasi Emosi Terhadap Prestasi Olahraga Atlet Disabilitas NPC Kota Surakarta. Interest: Jurnal Ilmu Kesehatan. https://doi.org/10.37341/interest.v8i2.1 73

Mudjianto, S., Widya, M., Nugraha, E., \& Ubad, C. (2017). Quality of Life Athlete 2016 Paralympic Jabar. IOP Conference Series: Materials Science and Engineering.

https://doi.org/10.1088/1757$899 X / 180 / 1 / 012223$

Mudjianto, Sufyar, Nugraha, E., Wahyudi, A., \& Ihsan, M. (2018). Quality of Life of West Java Paralympic Athletes. https://doi.org/10.5220/0007063604820 485

Pemerintah Republik Indonesia. (2014). Undang-Undang Republik Indonesia No 35 Tahun 2014 Tentang Perubahan Atas Undang-Undang Nomor 23 Tahun 2002 Tentang Perlindungan Anak. In UndangUndang Republik Indonesia.

Penggalih, M. H. S. T., Solichah, K. M., Pratiwi, D., Niamilah, I., Dewinta, M. C. N., Nadia, A., Kusumawati, M. D., Siagian, C., \& Asyulia, R. (2018). Identifikasi profil antropometri dan pemenuhan zat gizi atlet difabel tenis meja di Indonesia. Jurnal Keolahragaan. https://doi.org/10.21831/jk.v6i2.15676

Penney, D., \& McMahon, J. (2016). Highperformance sport, learning and culture: new horizons for sport pedagogues? Physical Education and Sport Pedagogy. https://doi.org/10.1080/17408989.2015. 1072511

Pertiwi, R. M., Nurhasan, N., \& Syam, T. A. R. (2018). Pengembangan Model Pembelajaran Sirkuit Untuk Membantu Pola Gerak Lokomotor, Non Lokomotor, dan Manipulatif Anak Down Syndrome. Jendela Olahraga. https://doi.org/10.26877/jo.v3i2.2452

Pitts, B. G., \& Shapiro, D. R. (2017). People with disabilities and sport: An exploration of topic inclusion in sport management. Journal of Hospitality, Leisure, Sport and Tourism Education. https://doi.org/10.1016/j.jhlste.2017.06. 003

Pratama, N. Y., \& Hudah, M. (2020).
Pendekatan Permainan Outbound Sirkuit Game Dalam Meningkatkan Kematangan Emosional Dan Spitual Melalui Pembelajaran Penjas Pada Siswa Smp N 1 Sumowono. Journal of Sport Coaching and Physical Education. https://doi.org/10.15294/jscpe.v5i1.365 66

Pujarina, F., \& Kumala, A. (2019). Modal Psikologi Terhadap Peak Perfomance. TAZKIYA JOURNAL OF PSYCHOLOGY. https://doi.org/10.15408/tazkiya.v7i2.13 468

Wardah, E. Y. (2019). Peranan Guru Pembimbing Khusus Lulusan NonPendidikan Luar Biasa (Plb) Terhadap Pelayanan Anak Berkebutuhan Khusus Di Sekolah Inklusi Kabupaten Lumajang. JPI (Jurnal Pendidikan Inklusi).

https://doi.org/10.26740/inklusi.v2n2.p 93-108

Widodo, A., Indraswati, D., Sutisna, D., Nursaptini, N., \& Novitasari, S. (2020). Identifikasi Bakat Peserta Didik Berkebutuhan Khusus (PDBK) di Madrasah Inklusi Kabupaten Lombok. JPI (Jurnal Pendidikan Inklusi). https://doi.org/10.26740/inklusi.v3n2.p 102-116

Yuliawan, E. R. (2017). Implementasi Kebijakan Pengelolaan Asesmen Anak Berkebutuhan Khusus Sekolah Inklusi Di Dinas Pendidikan Pemuda Dan Olahraga Provinsi Diy. Jurnal Kebijakan Pendidikan. 